Volume 2, Nomor 2, Maret 2022, hlm 122-129

BEMAS: JURNAL BERMASYARAKAT

p ISSN 27455866 | e ISSN 27457958

\title{
Pelatihan Komprehensif Menulis dan Menyunting Artikel Ilmiah Bagi Guru di Kabupaten Kendal
}

\author{
Uki Hares Yulianti ${ }^{1 *}$, Zulfa Fahmy ${ }^{2}$ \\ 1* Program Studi Pendidikan Bahasa Indonesia, Universitas Jenderal Soedirman, Purwokerto, Banyumas, \\ Jawa Tengah, Indonesia \\ ${ }^{2}$ Universitas Islam Negeri Walisongo Semarang, Jawa Tengah, Indonesia \\ 1* J1. Profesor DR. HR Boenyamin No.708, Dukuhbandong, Grendeng, Kec. Purwokerto Utara, Kabupaten \\ Banyumas, Jawa Tengah 53122 \\ ${ }^{2}$ J1. Walisongo No.3-5, Tambakaji, Kec. Ngaliyan, Kota Semarang, Jawa Tengah 50185
}

INFORMASI ARTIKEL

Article History:

Submission: 09-12-2021

Revised: 04-01-2022

Accepted: 06-01-2022

* Korespondensi:

Uki Hares Yulianti

ukihares@unsoed.ac.id

\begin{abstract}
ABSTRAK
Menulis dan menyunting artikel ilmiah merupakan salah satu proses meningkatkan kualitas profesional seorang guru, tetapi hal ini masih banyak belum dilakukan oleh guru karena keterbatasan kemampuan. Hal inilah akan menjadi masalah juga nantinya jika artikel ilmiah akan dikirimkan ke jurnal ilmiah. Oleh karena itu, perlunya pelatihan secara komprehensif untuk menulis dan menyunting artikel ilmiah. Pelatihan ini dilaksanakan di Kabupaten Kendal karena masih banyak guru yang belum maksimal dalam menulis, menyunting, dan mempublikasikannya ke jurnal ilmiah. Metode pada kegiatan pengabdian ini menggunakan Project Based Learning dikarenakan dari kegiatan ini menghasilkan luaran berupa artikel ilmiah yang dihasilkan oleh guru. Materi yang dipaparkan dalam penyuluhan, yaitu (1) Materi tahapan-tahapan menulis, (2) materi ketepatan diksi, kalimat, dan paragraf, (3) materi penggunaan tanda baca yang tepat, (4) tata tulis artikel ilmiah, (5) dan materi menyunting yang tepat dan efektif. Pada kegiatan ini juga menghasilkan artikel ilmiah tentang penulisan dan penyuntingan artikel ilmiah. Dari kegiatan ini juga peserta pelatihan berharap waktu untuk mengikuti pelatihan bisa lebih lama dan terjadwal agar menghasilkan kualitas yang lebih baik lagi.
\end{abstract}

Kata kunci: pelatihan komprehensif, menulis, menyunting, artikel

Comprehensive Training on Writing and Editing Scientific Articles for Teachers in Kendal District

\begin{tabular}{l} 
ABSTRACT \\
\hline Many teachers still cannot write and edit scientific articles that they have \\
produced. This is the main problem in this community service. Teachers \\
who are not able to write and edit scientific articles will face difficulties \\
in publishing their articles in related journals. Therefore, it takes \\
comprehensive training about writing and editing scientific articles. This \\
activity was conducted in Kendal Regency because there were still many \\
teachers who had not written, edited, and published their scientific \\
articles in related journals. The method of this community service was \\
project-based learning. This method demanded that every trainee could \\
produce a perfect scientific article. The materials presented in this \\
activity were diction, sentence, paragraph, EYD (Indonesian spelling \\
system), and systematics of scientific articles. The output of this training \\
was a comprehensive model of the edited and published scientific article. \\
\hline
\end{tabular}


In addition, the researchers obtained a collection of perfect articles from the participants of the training. This activity also produced a scientific article about writing and editing scientific articles.

Keywords: comprehensive training, writing, editing, articles

\section{PENDAHULUAN}

Menulis dan menyunting artikel ilmiah merupakan salah satu proses meningkatkan kualitas profesional seorang guru, tetapi hal ini masih banyak belum dilakukan oleh guru karena keterbatasan kemampuan[1]. Menulis dan menyunting karya ilmiah dianggap masalah yang tidak begitu penting. Padahal, peran bahasa sebagai sarana penyampai pesan ini sangat vital. Andai saja belum mampu menulis berbahasa Indonesia dengan baik dan benar, maka ketersampaian pesan akan menjadi masalah[2].

Hal ini juga terkait dengan pengembangan profesionalitas guru. Ada beberapa kegiatan untuk mengembangkan profesionalitas guru[3], yaitu (1) menemukan teknologi di bidang pendidikan, (2) menulis karya tulis ilmiah di bidang pendidikan, (3) membuat peralatan pelajaran atau peraga, dan (4) menciptakan karya tulis ilmiah, serta aktif mengikuti berbagai kegiatan dalam mengembangkan kurikulum[4][5][6].

Atas dasar hal tersebut, dapat diartikan bahwa pengembangan profesionalitas guru salah satunya dapat dilakukan dengan membuat karya ilmiah. Salah satu karya ilmiah adalah artikel. Seperti yang kita ketahui artikel Menurut Kamus Besar Bahasa Indonesia (1988:49) dalam (Gunawan, 2008) mengemukakan artikel adalah karya tulis lengkap dalam majalah, surat kabar, dan sebagainya[7]. Sedangkan artikel ilmiah[8] diartikan sebagai karya tulis yang dirancang untuk dimuat dalam jurnal atau buku kumpulan artikel yang ditulis dengan tata cara ilmiah dan mengikuti pedoman atau konvensi ilmiah yang telah disepakati atau ditetapkan.

Karya ilmiah yang sudah dibuat tentunya tidak begitu saja selesai setelah melakukan penelitian. Artinya harus ada tindak lanjut terkait dengan hasil penelitian yang telah dilakukan oleh para guru. Hasil penelitian/karya ilmiah yang dilakukan oleh guru[9], setidaknya bermanfaat bagi diri sendiri, tetapi akan menjadi lebih berharga jika dapat bermanfaat untuk orang lain (guru lain). Maka dari itu, beberapa dinas terkait telah menerbitkan jurnal hasil penelitian guru diantaranya Didaktika dan Jurnal Pendidikan[10]. Jurnal-jurnal tersebut membutuhkan naskah yang sempurna, baik secara gagasan maupun secara pengemasan (kebahasaan). Banyak sekali guru yang benar-benar belum mampu menguasai aspek-aspek kebahasaan dalam menuliskan jurnalnya[11][12]. Akan tetapi untuk dimuat di dalam jurnal tentunya ada proses seleksi yang ketat. Salah satu proses seleksi yang dilakukan adalah kualitas artikel. Kualitas artikel selain isinya yang baik, tentunya juga mengenai masalah diksi, ejaan, dll. Persoalan menentukan diksi didasari oleh dua hal, yaitu ketepatan diksi dan kesesuaian diksi. Doyin (2015:35-38) menyatakan bahwa ketepatan diksi adalah kesanggupan sebuah kata dalam membangun imajinasi pembaca sesuai dengan yang dipikirkan penulis[13]. Artinya sebuah kata harus benar-benar bisa mewakili konsep yang dipikirkan penulis. Kesesuaian diksi adalah kecocokan sebuah kata jika digunakan dalam situasi dan konteks tertentu. Sebuah kata mungkin saja tepat digunakan tetapi belum tentu cocok digunakan dalam semua konteks. Selain itu juga kalimat yang digunakan dalam artikel ilmiah adalah kalimat yang efektif. Kalimat efektif adalah kalimat yang jelas, benar, dan hemat sehingga mudah dipahami oleh orang lain secara tepat (Doyin, 2015:39)[13]. Sebuah kalimat dikatakan efektif apabila dapat mewakili secara tepat isi pikiran atau perasaan. Kalimat efektif mampu menimbulkan kembali gagasan-gagasan pada pikiran pembaca/pendengar identik dengan apa yang dipikirkan pembicara/penulis (Keraf, 1994:35). Oleh 
karena itu, jika kita hendak membuat kalimat efektif[14], kita harus memperhatikan beberapa hal diantaranya (1) ketepatan gagasan, (2) koherensi yang kompak, (3) penekanan kalimat, dan (4) memiliki kehematan.

Berdasarkan amatan yang dilakukan oleh tim pengabdian, guru-guru di Kabupaten Kendal belum banyak mengirimkan artikel ilmiahnya ke jurnal-jurnal terkait. Data dari jurnal Didaktika dan Metodika, jumlah guru dari kabupaten yang mengirim artikelnya ke jurnal ini hanya 4 dari 20 artikel. Itu pun belum tentu lolos masuk ke jurnal karena berbagai kriteria persyaratan diantaranya kebahasaan.

Atas dasar gambaran masalah tersebut, tim pengabdian ini terpanggil untuk mengatasi hal tersebut dengan melakukan pengabdian komprehensif. Selama ini, pelatihan, workshop, atau pun seminar tentang penulisan artikel ilmiah telah banyak dilakukan. Namun, hal tersebut belum juga mengatasi permasalahan. Maka dari itu, pelatihan komprehensif harus segera dilakukan. Pelatihan komprehensif adalah pelatihan yang menyeluruh, baik dari pemberian materi, latihan, evaluasi, hingga praktik langsung. Setelah pelatihan ini dapat dipastikan dapat menghasilkan artikel ilmiah yang lolos ke jurnal.

Berdasarkan latar belakang tersebut, dapat dirumuskan beberapa masalah sebagai berikut: (1) Bagaimana cara melatih keterampilan menulis dan menyunting artikel ilmiah untuk guru di Kabupaten Kendal; (2) Bagaimana cara mengevaluasi keterampilan menulis dan menyunting artikel ilmiah untuk guru di Kabupaten Kendal; dan (3) Bagaimana cara mempraktikan keterampilan menulis dan menyunting artikel ilmiah untuk guru di Kabupaten Kendal.

Pelatihan ini memiliki target utama yaitu dengan adanya pelatihan yang lebih komprehensif, guru di Kabupaten Kendal dapat menulis dan menyunting dari karya ilmiah atau artikel ilmiah secara sempurna. Ada dua target terinci yaitu target jangka pendek dan target jangka panjang.

Target jangka pendek dari pelatihan komprehensif ini yaitu (1) guru dapat menulis artikel ilmiah dari penelitian PTK yang telah dilaksanakan; (2) guru dapat menyunting artikel ilmiah yang telah ditulisnya secara sempurna; dan (3) guru juga mengirimkan artikel ilmiahnya ke jurnal ilmiah yang sesuai dengan bidangnya. Sedangkan untuk target jangka panjang dari pelatihan komprehensif ini adalah guru di Kabupaten Kendal dapat menulis dan menyunting artikel ilmiah secara permanen dan berkelanjutan.

Ada beberapa studi yang mengungkapkan masalah serupa; Purwanto (2010) dalam pengabdiannya juga melakukan pelatihan penulisan karya ilmiah[15]. Dalam Penelitiannya juga bertujuan untuk meningkatkan dalam menulis karya ilmiah. Hanya pengabdian yang dilakukan oleh Purwanto (2010) dia hanya fokus memberikan pelatihan saja tanpa adanya latihan praktik menulis[15]. Subjek dalam pengabdian yang dilakukan Purwanto (2010) ini adalah guru-guru SD di Yogyakarta[15]. Hal inilah yang membedakan juga dengan pengabdian ini. Pengabdian ini ditujukan untuk guru-guru di Kabupaten Kendal. Jadi pelatihan menulis artikel merupakan hal yang penting untuk para guru. Hal ini berguna dalam membantu guru untuk menuangkan hasil penelitiannya dalam bentuk tulisan. Selain itu, perlunya pelatihan menulis yang perlu adanya bimbingan dari yang lebih ahli di bidangnya. Hal ini untuk membantu guru menghasilkan tulisan yang lebih baik dan layak untuk dimuat di jurnal.

\section{METODE PELAKSANAAN}

Sasaran kegiatan ini adalah guru di Kabupaten Kendal. Pengabdian masyarakat yang dilaksanakan di Kabupaten Kendal ini dilakukan dengan metode memberikan penyuluhan, memberikan pelatihan yang komprehensif, dan melakukan latihan menulis dan menyunting secara langsung (simulasi). Sosialisasi atau memberikan penyuluhan dilakukan dengan memberikan materi berupa pengetahuan tahapan menulis artikel ilmiah dan materi penyuntingan. Materi yang dipaparkan dalam penyuluhan, yaitu (1) Materi tahapan-tahapan menulis, (2) materi ketepatan diksi, kalimat, dan paragraf, (3) materi 
penggunaan tanda baca yang tepat, (4) tata tulis artikel ilmiah, (5) dan materi menyunting yang tepat dan efektif.

Pelaksanaan pengabdian ini juga dilaksanakan oleh tim pengabdian kepada masyarakat yang mempunyai kelayakan untuk melaksanakan kegiatan pelatihan komprehensif menulis dan menyunting artikel ilmiah untuk Guru di Kabupaten Kendal. Semua anggota tim adalah profesional di bidangnya. Kelayakan tim pengabdian ini adalah semua anggota tim pengabdian merupakan dosen bahasa dan sastra Indonesia yang mempunyai kemampuan profesional untuk melaksanakan pengabdian. Kemampuan yang diperlukan dalam pelatihan ini adalah (1) pemahaman terhadap Ejaan yang Disempurnakan (EYD), (2) Pemahaman terhadap tata kaidah kebahasaan, dan (3) kemampuan untuk menularkan ilmu pengetahuan secara menarik dan efektif.

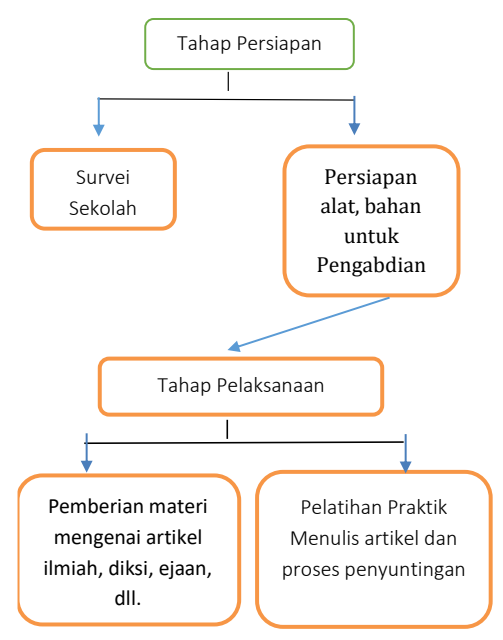

Gambar 1. Diagram alur kegiatan pengabdian masyarakat

\section{HASIL DAN PEMBAHASAN}

\subsection{Hasil}

Pelatihan menulis dan menyunting artikel ilmiah komprehensif di Kabupaten kendal dilaksanakan di sekolahan yang diikuti oleh 30 peserta. Para guru menyambut dengan antusias adanya pelatihan ini. Antusias para guru yang sudah siap memberikan arti bahwa pelatihan menulis dan menyunting artikel ilmiah komprehensif sungguh berarti bagi mereka. Kegiatan dimulai tepat jam 08.00 WIB. Acara dibuka oleh Ketua MGMP Guru Bahasa Indonesia Kabupaten kendal, kemudian diserahkan sepenuhnya kepada Tim Pengabdi.

Desain Project Based Learning dilakukan dalam proses penyampaian materi yang didasari dengan sebuah proyek. Dalam Project Based Learning peserta belajar dalam situasi problem yang nyata, yang dapat melahirkan pengetahuan yang bersifat permanen dan mengorganisir proyek-proyek dalam pembelajaran (Thomas, 2000)[16]. Dalam konteks kegiatan pengabdian ini, proyek utamanya adalah penulisan dan penyuntingan artikel ilmiah. Pada kegiatan program pengabdian ini setiap guru mulai menulis artikel ilmiah dari penelitian yang telah dilaksanakan. Pada tahap penyampaian materi dijelaskan oleh para pakar yang sesuai dengan bidangnya di penulisan artikel ilmiah dan pakar penyuntingan. Pemaparan materi dilakukan dengan ceramah yang kreatif yang dikombinasikan dengan pemberian contoh kasus yang ada di sekitar, dan lain sebagainnya. Pelatihan komprehensif ini dilakukan dengan dua tahapan, yaitu:

\section{A. Metode ceramah}

Pada metode ceramah menggunakan bantuan media laptop dan LCD. Menjelaskan materi menulis dan menyunting artikel ilmiah komprehensif secara rinci yang meliputi: materi tentang ketepatan diksi, 
kalimat, paragraf, dan tanda baca; materi tentang sistematika penulisan karya ilmiah; materi tentang teknik menyunting karya ilmiah yang tepat dan efisien. Sesi ceramah diisi dengan pemberian teori mengenai penulisan artikel ilmiah dari hasil penelitian sesuai dengan gambar 2.

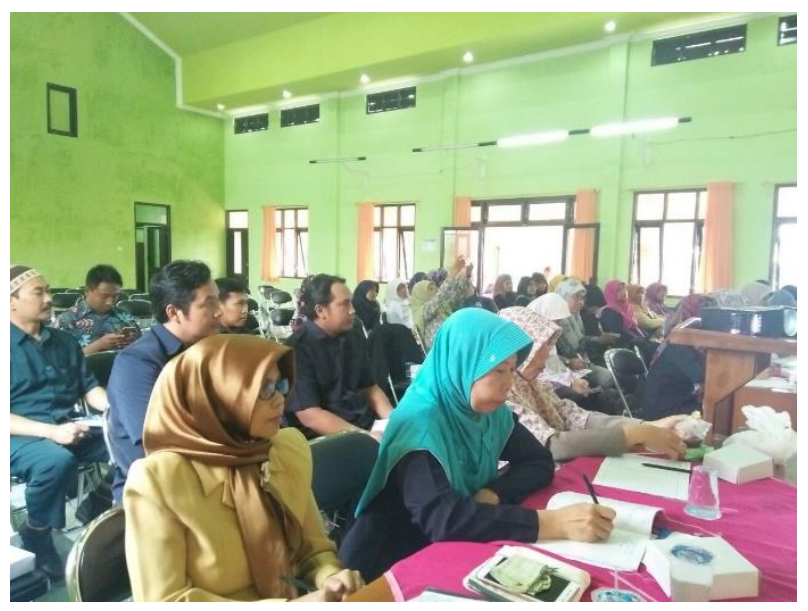

Gambar 2. Pelatihan komprehensif menulis dan menyunting artikel ilmiah pada sesi ceramah.

B. Drill practice atau latihan praktik

Pada metode ceramah sebelumnya yang berupa pemaparan materi, maka pada tahapan ini dilanjutkan dengan mengaplikasikan dari teori yang sudah didapatkan dengan kenyataan.Pada sesi ini guru-guru diminta untuk mempraktikkan apa yang sudah disampaikan.

Terdapat tiga materi yang disampaikan dalam kegiatan pengabdian ini. Semua dilakukan secara komprehensif dan menarik. Ketiga materi tersebut adalah (1) materi tentang ketepatan diksi, kalimat, paragraf, dan tanda baca, (2) materi tentang sistematika penulisan karya ilmiah, (3) materi tentang teknik menyunting karya ilmiah yang tepat dan efisien. Penyampaian materi dilakukan secara bertahap dengan memperhatikan situasi, suasana, dan kesiapan peserta kegiatan pengabdian.

Pelatihan menulis artikel ilmiah memang belum bisa dilakukan secara maksimal dikarenakan guru saat berlatih hanya baru bisa menulis beberapa paragraf saja karena keterbatasan waktu. Hal inilah yang membuat berlatih menulis harus dilakukan secara mandiri dan dilanjutkan di lain hari. Selain itu, para guru yang sudah memulai praktik penulisan menulis dan menyunting artikel ilmiah komprehensif bisa konsultasi melalui telepon dan email. Sehingga di pertemuan selanjutnya waktu yang digunakan bisa lebih efektif[17].

Pelaksanaan pelatihan menulis dan menyunting artikel ilmiah komprehensif[18], dipandang penting mengikutsertakan MGMP sebagai panitia sekaligus peserta, meskipun belum mampu merekrut lebih banyak. Paling tidak dengan adanya MGMP yang ikut menangani baik langsung maupun tidak, akan mempermudah pelaksanaan kegiatan.

Pada kegiatan pemaparan materi, peserta pelatihan begitu antusias mendengarkan pemaparan materi dari narasumber. Peserta yang merupakan guru-guru menyampaikan jika sudah sering mengikuti pelatihan penulisan artikel ilmiah, akan tetapi untuk mempraktekannya masih sering menghadapi kesulitan. Guru yang mengikuti pelatihan juga beberapa sudah mengikuti pendidikan S2/magister, akan tetapi juga belum memahami mengenai artikel ilmiah dan bagaimana menyunting yang tepat dan efisien.

Guru di Kabupaten Kendal mengalami kesulitan paling mendasar yaitu menulis artikel ilmiah karena tidak terbiasa menulis. Artikel ilmiah dihasilkan dari hasil kegiatan penelitian yang telah dilaksanakan. Artikel ilmiah yang baik tentunya juga dihasilkan dari laporan penelitian yang baik. Dimana laporan penelitian dihasilkan dari kegiatan pelaksanaan penelitian yang benar. Kegiatan pelaksanaan yang baik tentunya juga didapatkan dari proposal penelitian yang baik. Rupanya banyak 
guru di Kabupaten Kendal belum membuat proposal ketika melakukan penelitian. Hal inilah yang mebuat laporan penelitian yang dihasilkan kurang baik. Hal ini tentunya juga berakibat dengan kualitas artikel ilmiah yang dihasilkan juga kurang maksimal.

Selama program pengabdian berupa pelatihan ini berlangsung, peserta diberi kesempatan untuk melakukan kegiatan konsultasi melalui email. Akan tetapi kesempatan ini tidak banyak dilakukan oleh peserta. Para peserta memanfaatkan konsultasi hanya saat pertemuan terakhir. Para peserta kebingungan karena tidak memiliki bahan untuk ditulis karena banyak yang belum melakukan penelitian.

\subsection{Pembahasan}

Sebagaimana dijelaskan di atas, pelatihan menulis dan menyunting artikel ilmiah komprehensif ini dibagi menjadi tahap pembelajaran dan latihan. Sasaran pelatihan ini adalah bagaimana menuliskan artikel ilmiah yang efektif, efisien, dan praktis. Para guru diajarkan bagaimana menuliskannya dengan cara mengikuti alur yang ada. Dimulai dengan mengungkapkan kondisi ideal yang harus dicapai dalam proses pembelajaran. Kemudian dilanjutkan dengan identifikasi masalah yang berasal dari siswa, guru, sarana, dan prasarana serta lingkungan. Setelah itu, dipaparkan solusi yang ditawarkan termasuk didalamnya kelebihan dan rationale pendekatan, metode, teknik atau media yang ditawarkan.

Program kegiatan pengabdian ini dapat dikatakan berlangsung dengan baik. Selama proses berlangsung, peserta pelatihan mengikuti kegiatan ini dengan santai dan penuh semangat. Terlihat benayak yang aktif saat kegiatan ini berlangsung, baik pertanyaan ataupun curhat keluh kesah yang dirasakan dalam proses menulis. Selama proses berlangsung, baik sesi pertama maupun sesi kedua, para peserta bertanya banyak hal yang berkaitan dengan proses penulisan dan unsur yang harus ditulis dalam artikel ilmiah. Semua peserta tetap mengikuti seluruh proses pelatihan sampai kegiatan berakhir. Bisa dikatakan tidak ada halangan selama kegiatan berlangsung. Kegiatan dimulai pada pertemuan pertama tepat waktu dan berakhir 2 jam lebih lama dari waktu yang direncanakan karena banyaknya pertanyaan yang masuk.

Pelatihan menulis dan menyunting artikel ilmiah komprehensif yang dilaksanakan pada guru-guru di Kabupaten kendal ini berhasil, yakni berdasarkan hasil evaluasi yang telah dilakukan secara seksama, baik dalam evaluasi materi maupun evaluasi kemanfaatan. Dalam evaluasi materi, meskipun tidak semua peserta melakukan praktik, namun dari perwakilan yang menulis artikel ilmiah terlihat sudah mulai bisa menuangkan gagasannya.

Kegiatan pelatihan komprehensif menulis dan menyunting artikel ilmiah ini yang direncanakan hanya diikuti 30 guru, akan tetapi pelaksanaanya mencapai 45 peserta. Hal ini terlihat bahwa guru-guru asih butuh pendampingan dan pelatihan yang komprehensif dalam menulis dan menyunting artikel ilmiah. Secara kuantitatif yang mengikuti pelatihan ini begitu antusias mulai dari awal hingga proses pendampingan pelatihan praktik menulis artikel ilmiah.

Sebelum penutupan, ketika peserta pelatihan penulisan penelitian menulis dan menyunting artikel ilmiah komprehensif diberi pertanyaan apakah mereka mendapatkan pengetahuan dan pengalaman baru mengenai pelatihan menulis dan menyunting artikel ilmiah komprehensif, peserta secara kompak menjawab iya. Artinya, mereka sepakat bahwa evaluasi secara kemanfaatan, mereka telah mendapatkan pengetahuan dan pengalaman baru dalam penulisan menulis dan menyunting artikel ilmiah komprehensif ini. Ketika sesi tanya jawab, bahkan seorang peserta menyatakan termotivasi untuk mulai menulis artikel dan berharap artikelnya dimuat di jurnal. Hambatan dari kegiatan ini berupa keterbatasan waktu pelaksanaan sehingga peserta kurang maksimal dalam membuat penulisan menulis dan menyunting artikel ilmiah komprehensif.

\section{SIMPULAN}

Berdasarkan hasil pelaksanaan kegiatan penulisan menulis dan menyunting artikel ilmiah komprehensif yang telah dilaksanakan dapat disimpulkan bahwa kegiatan pengabdian ini dapat 
Pelatihan Komprehensif Menulis dan Menyunting Artikel Ilmiah Bagi Guru di

Kabupaten Kendal

menginspirasi dan sekaligus membantu guru dalam penelitian, khususnya artikel ilmiah, yang hasilnya dapat menjadi perbaikan dalam pembelajaran baik yang dilakukan oleh guru tersebut maupun guru-guru lain yang mengajarkan topik tersebut. Guru juga merasa senang dengan adanya pelatihan, namun dirasakan waktu yang disediakan untuk praktik penulisannya masih kurang. Selain itu, guru mulai termotivasi menulis artikel ilmiah.

\section{UCAPAN TERIMA KASIH}

Terima kasih kepada MGMP Bahasa Indonesia Kabupaten Kendal yang telah membantu pelaksanaan program pelatihan ini.

\section{DAFTAR PUSTAKA}

[1] A. Surya, F. Azharul, W. Wilarso, M. Idris, Y. Z. Azziqi, and I. H. Retno, "Improving High School and Vocational School Teachers in Writing Skill," J. Dedik., vol. 17, no. 1, p. 64, 2020, doi: 10.22219/dedikasi.v17i1.12021.

[2] F. Istiara, N. Adijaya, and F. Helmanto, "Pendampingan Pembelajaran Daring di Sekolah Dasar Dengan Pendayagunaan Google Form," BEMAS J. Bermasyarakat, vol. 2, no. 1, pp. 60-65, 2021, doi: 10.37373/bemas.v2i1.122.

[3] A. Widayati, "Penelitian Tindakan Kelas," J. Pendidik. Akunt. Indones., vol. 6, no. 1, 2014, doi: 10.21831/jpai.v6i1.1793.

[4] M. G. Aditama, Prasetyawan Aji Sugiharto, Eki Nurwulandari, and Aisyiah Happy Hardiyani, "Meningkatkan Kemampuan Guru SMK Dalam Pembelajaran Jarak Jauh Melalui In-House Training," BEMAS J. Bermasyarakat, vol. 2, no. 1, pp. 53-59, 2021, doi: 10.37373/bemas.v2i1.130.

[5] Henri, "UPAYA MENINGKATKAN KOMPETENSI GURU SEKOLAH DASAR MELALUI PENULISAN KARYA ILMIAH,” prihastuti ekawatiningsih, Kokom Komar. Rizqie Auliana, Fitri Rahmawati, vol. 8, no. 1, 2013.

[6] Abdul Majid, "Implementasi Kurikulum 2013," p. 38, 2014.

[7] W. Gunawan, “6 Trik Menjadi Penulis Artikel.” LPM UNPAD Bandung, p. 108, 2005.

[8] B. N. Tanjung and Ardial, Pedoman penulisan karya ilmiah ( Proposal, Skripsi, Dan Tesis ) Dan mempersiapkan diri menjadi penulis artikel Ilmiah. 2010.

[9] E. Suharini and E. Kurniawan, "Jurnal panjar," J. Panjar, vol. 1, no. 2, pp. 114-117, 2019.

[10] H. Fitria, M. Kristiawan, and N. Rahmat, "Upaya Meningkatkan Kompetensi Guru Melalui Pelatihan Penelitian Tindakan Kelas," Abdimas Unwahas, vol. 4, no. 1, pp. 14-25, 2019, doi: 10.31942/abd.v4i1.2690.

[11] M. Afandi, E. Chamalah, and O. P. Wardani, Model Dan Metode Pembelajaran Di Sekolah, vol. 392, no. 2. 2013.

[12] Saryati, "Upaya Peningkatan Kompetensi Paedagogik Guru Sekolah Dasar," Bahana Manaj. Pendidik. J. Adm. Pendidik., vol. 2, no. 1, pp. 669-681, 2014.

[13] W. Doyin Mukh, Bahasa Indonesia : pengantar penulisan karya ilmiah, ISBN: 978-602-846701-8. Semarang : Universitas Negeri Semarang Press, 2009.

[14] Gorys Keraf, sebuah pengantar kemahiran bahasa, ISBN 9794290025. Ende, Flores: Nusa Indah, 1994.

[15] Nurtanio Agus Purwanto, "MENINGKATKAN KEMAMPUAN MENULIS MELALUI PELATIHAN PENULISAN KARYA ILMIAH BAGI GURU SEKOLAH DASAR," 2012. [Online]. Available: http://eprints.uny.ac.id/id/eprint/3497.

[16] B. Pearlman and J. W. Thomas, "Bob Pearlman Home Project-Based Learning 21st Century Learning A REVIEW OF RESEARCH ON PROJECT-BASED LEARNING,” 2000, [Online]. 
Available: http://www.bie.org/research/study/review_of_project_based_learning_2000.

[17] A. F. Hery Soegiharto and Sudarman, "Pendampingan Pembelajaran Keterampilan Secara Daring di Pondok Pesantren Tarbiyatul Iman Malang," BEMAS J. Bermasyarakat, vol. 2, no. 1, pp. 66-75, 2021, doi: 10.37373/bemas.v2i1.131.

[18] H. ZM, M. Muntari, and A. W. Jufri, "Pelatihan Penulisan dan Penyuntingan Karya Ilmiah bagi Guru-Guru MTS dan MA Pondok Pesantren Azziziyah Kapek di Kecamatan Gunungsari Kabupaten Lombok Barat," J. Pengabdi. Magister Pendidik. IPA, vol. 1, no. 1, 2019, doi: 10.29303/jpmpi.v1i1.219. 